\title{
Pragmatism, Practices, and Human Rights
}

\section{Robert Lamb}

\section{Abstract}

This paper is an intervention in recent debates about conceptual and normative theorizations of human rights, which have been increasingly characterised by a divide between 'moral' and 'practice-based'/'political' understandings. My aim is to articulate an alternative, pragmatist understanding of human rights, one that is importantly distinct from the practice-based account with which it might be thought affiliated. In the first part of the paper, I reveal the fundamental flaw in the practice-based account of human rights: I argue that it is undermined by the ontological thesis at its heart, which naturalises and reifies political arrangements and institutions that are radically contingent. In the second part, I identify, and outline the attractiveness of, a pragmatist normative account of human rights. In contrast to the practicebased approach, this pragmatist account construes human rights in ideational terms. The pragmatist understanding accepts both the contingency of our practices and the cultural limits to moral justification, while nevertheless retaining a commitment to the enterprise of normative philosophical conversation. I argue, in contrast to prevailing interpretations, that the international theory advanced by John Rawls exemplifies a pragmatist account of human rights and points a way forward for theoretically fruitful but appropriately circumscribed analysis of the concept.

Keywords

Human rights; pragmatism; Rawls; Rorty; practices

\section{Biography}

Robert Lamb is Associate Professor and Head of the Politics Department at the University of Exeter. He is the author of Thomas Paine and the Idea of Human Rights (Cambridge University Press, 2015) and has published widely on the history of modern political thought and contemporary political philosophy.

\section{Acknowledgements}

Versions of this paper were presented to the University of Exeter's Political Theory reading group and Human Rights and Democracy Forum, to the University of Glasgow's Politics seminar, and to the Midwest Political Science Association conference in Chicago. I am very grateful to those audiences for their engagement, as well as to Sarah Lucas, Simon Townsend and two anonymous referees for their constructive criticism of earlier drafts.

\section{Institutional address}

Department of Politics, Amory Building, University of Exeter, Rennes Drive, Exeter, EX4 4RJ.

\section{Email address}

r.lamb@exeter.ac.uk 


\section{Pragmatism, Practices, and Human Rights}

\section{Robert Lamb}

\section{Introduction}

There has been an explosion of interest in human rights within normative political theory in recent years. As scholarly debates have developed, one particularly noteworthy theoretical divide has emerged, between those who offer an idea-focused, moral account of human rights on the one hand, and those who advocate a practice-based, political account on the other. The disagreement turns on whether the conceptual and normative meaning of human rights should be gleaned from consideration of it as an abstract moral idea or through analysis of its practical role in real-world international politics. ${ }^{1}$ Since the articulation of this distinction, philosophers have advanced further defences from within each camp, and something of an impasse has been reached. ${ }^{2}$ In his assessment of contemporary theoretical debates, Vittorio Bufacchi concludes that 'the only consensus about human rights is that there is no consensus'. ${ }^{3}$ In a less charitable judgement, Jeremy Waldron complains that 'the whole field is a bit of a mess'.

In this paper, I address the debate between moral and practice-based approaches to human rights and present a way out of the current scholarly impasse. I identify, and outline the attractiveness of, a distinct pragmatist understanding of human rights that appears to

\footnotetext{
${ }^{1}$ See the contributions to Adam Etinson (ed.), Human Rights: Moral or Political? (Oxford: Oxford University Press, 2018); Rowan Cruft, S. Matthew Liao, and Massimo Renzo (eds.) Philosophical Foundations of Human Rights (Oxford: Oxford University Press, 2015).

${ }^{2}$ See, for example, Pablo Gilabert, 'Humanist and Political Perspectives on Human Rights', Political Theory 39: 4 (2011), pp. 439-67; S. Matthew Liao and Adam Etinson, 'Political and Naturalistic Conceptions of Human Rights: A False Polemic?', The Journal of Moral Philosophy 9:3 (2012), pp. 327-52; Laura Valentini, 'Human Rights, Freedom, and Political Authority', Political Theory 40: 5 (2012a), pp. 573-60; Allen Buchanan, The Heart of Human Rights (Oxford: Oxford University Press, 2013); Andrea Sangiovanni, 'Beyond the PoliticalOrthodox Divide: The Broad View' in A. Etinson (ed.), Human Rights: Moral or Political? (Oxford: Oxford University Press, 2018), pp. 174-199; Anita Sophia Horn, 'Moral and Political Conceptions of Human Rights: Rethinking the Distinction', The International Journal of Human Rights 20: 6 (2016), pp. 724-43; Vittorio Bufacchi, 'Theoretical Foundations of Human Rights', Political Studies 66: 3 (2018), pp. 601-17.

${ }^{3}$ Buffachi, 'Theoretical Foundations', p. 601.

${ }^{4}$ Jeremy Waldron, 'Human Rights: A Critique of the Raz/Rawls Approach' in Etinson (2018), pp. 117-138, at p. 136.
} 
avoid the deficiencies that bedevil the moral and practice-based approaches. In doing so, I provide a novel, but vital, differentiation of the pragmatist understanding from the recently ascendant practice-based approach with which it may mistakenly be thought related or even equivalent. As Matthew Festenstein points out, pragmatists hold a 'methodological commitment to the primacy of practice', which means that 'inquiry is a problem-solving activity', wherein 'we can only begin to reason and deliberate on the basis of the beliefs and practices that we have'. It may therefore be tempting to conflate the two approaches and think that pragmatism implies an endorsement of the thesis that practices have interpretive authority in the understanding of political concepts. As I will show, however, we can make sense of a coherent and attractive pragmatist understanding of human rights that has nothing substantively in common with the practice-based approach. I show that rather than misguidedly insisting on the interpretive authority of practices in political analysis, pragmatism instead licences a concern with ideas. It thus can embolden a (significantly augmented) moral understanding of human rights.

The structure of the paper is as follows. In the first part, I tackle the debate between moral and practice-based approaches directly, primarily to expose problems with the latter. Advocates of a practice-based account are united in their insistence that any conceptual and normative account of human rights must defer to its practical function and role in international politics. I argue that the practice-based account fails fundamentally on its own terms and in a way that points us firmly towards the primacy of an ideational understanding of the concept. I show that the practice-based understanding of human rights implies a dangerous reification of, and deference to, established political institutions. This reification is based on a misunderstanding of the nature of practices: the practice-based theory relies on a dubious ontological commitment that naturalises political arrangements that should be

\footnotetext{
${ }^{5}$ Matthew Festenstein, 'Pragmatism, Realism, and Moralism', Political Studies Review 14: 1 (2016), pp. 39-49, at p. 42.
} 
understood as rooted in individual intentionality and therefore radically contingent. Against advocates of the practice-based approach, I conclude that human rights must be construed in ideational rather than practical/institutional terms.

In the second part of the paper, I outline an alternative, pragmatist normative theorization of human rights. Such a pragmatist account can, I suggest, retain a focus on human rights as a moral idea while nevertheless responding to the political and philosophical scepticism that motivates the practice-based approach. I argue that we can plausibly appreciate moral theorizations of human rights as expressions of normative values that are universalistic in content, but culturally particular in terms of their justificatory scope. To explain and vindicate this argument, I turn first briefly to the work of Richard Rorty, and then in much more detail to that of John Rawls. In a sympathetic explanation of his normative international theory, I demonstrate that Rawls' understanding of human rights has been persistently misunderstood and misrepresented by advocates of the practice-based approach (who mistakenly regard him as an ally), as well as its critics. I show how Rawls' international theory exemplifies a pragmatist philosophical account of human rights that is characterised by an analysis of moral values rather than political practices. In contrast to the reifications of the practice-based approach to human rights and what might be thought the naïve universalism of the moral approach, Rawls' pragmatist alternative draws attention to the contingency of our inherited traditions, while simultaneously enabling productive philosophical conversation about the substantive content of a political value with considerable emancipatory potential.

\section{PART I: The Practice-Based Approach to Human Rights and the Primacy of Ideas}

The practice-based approach to human rights that has emerged in recent scholarship has been developed in response to a perceived moralistic theoretical orthodoxy. The exemplary 
expression of the contemporary moral approach is James Griffin's On Human Rights. ${ }^{6}$ In that work, Griffin aims to illuminate the normative and conceptual distinctness of human rights. For him, the idea of human rights has a unique place in our normative vocabulary. A concern with human rights is not, he points out, equivalent or reducible to a broader interest in the concepts of justice or morality. ${ }^{7}$ He thus intends his analysis to account for the theoretical specificity of human rights, such that we can both explain its moral underpinnings and determine its practical, political entailments. ${ }^{8}$ Griffin argues that both the justificatory grounding for, and the practical content of, the idea of human rights can be linked to a distinct concept of 'personhood' rather than any more general moral value (such as equality) or any claimed biological fact about the human species (such as any account of our physical features). ${ }^{9}$ He suggests that analysis of personhood - and the commitment to 'normative agency' it implies - can provide a means to both identify the bearers of human rights and reveal the appropriate political manifestations of that idea. ${ }^{10}$

Griffin describes his own method as a 'bottom-up' conceptual explication, and he therefore thinks that personhood is not in itself sufficient to give the idea of human rights determinate content. His theory is thus explicitly committed to a twin grounding of personhood with the 'practicalities' that will be relevant to determining the normative content of human rights. ${ }^{11}$ It is nevertheless a chiefly abstract and philosophical approach to human rights and involves the dialectical reasoning and conceptual analysis rooted in appeals to moral and linguistic intuitions typical of contemporary moral philosophy. ${ }^{12}$ While one of Griffin's objectives is to establish a framework to determine the normative political demands

\footnotetext{
${ }^{6}$ James Griffin, On Human Rights (Oxford: Oxford University Press, 2008).

${ }^{7}$ Ibid, p. 43.

${ }^{8}$ Ibid, pp. 29-56.

${ }^{9}$ Ibid, pp. 33-37.

${ }^{10}$ Ibid, pp. 83-85, 149-187.

11 Ibid, pp. 3-4, 29-30, 37-39.

${ }^{12} \mathrm{He}$ maintains that his theory does not offer 'a derivation of human rights from normative agency' (Ibid, p. 4), but seeks to unpack a coherent conceptual account that overcomes worries about its indeterminacy.
} 
of human rights, his approach does not involve much reference - and certainly no deference to human rights law or practice. ${ }^{13}$ For him, 'we should be neither surprised nor especially troubled by some discrepancy between the list of human rights that emerges from a theorist's deliberations and the lists that are enshrined in law'. ${ }^{14}$ The role of the philosopher is thus not to consult legal or political practice as an authoritative source, but instead to provide a comprehensive account of the idea of human rights in moral terms.

Dissatisfaction with this moralistic understanding of human rights has motivated advocates of the practice-based alternative, which has been developed most programmatically by Charles Beitz. ${ }^{15}$ In his (somewhat inappositely titled) The Idea of Human Rights, Beitz ties the meaning of the concept to its practical instantiation in the world. He laments 'philosophers [who] have conceived of human rights as if they had an existence in the moral order that can be grasped independently of their embodiment in international doctrine and practice'. ${ }^{16}$ In place of the moralistic assumption that human rights 'express and derive their authority from some...deeper order of values', Beitz insists instead that an adequate understanding of the concept must 'take account of the functions that the idea of a human right is meant to play, and actually does play, in the practice' of international politics. ${ }^{17}$ The definitive characteristic of Beitz's approach is that it is the practice of human rights - rather than any more fundamental moral or ideational commitment - that determines its conceptual and normative meaning. For him, crucially, 'a practical approach does more than notice that a practice of human rights exists; it claims for the practice a certain authority in guiding our

\footnotetext{
${ }^{13}$ Ibid, pp. 5-6, 13-14.

${ }^{14}$ Ibid, p. 191.

${ }^{15}$ In addition to the work of Griffin, Beitz also cites the capabilities theories advanced by Martha Nussbaum and Amartya Sen as 'naturalistic' approaches to human rights (Charles Beitz, The Idea of Human Rights (Oxford: Oxford University Press, 2009), pp. 48-72).

${ }^{16}$ Beitz, The Idea of Human Rights, p. 7.

${ }^{17}$ Ibid, pp. 7-8.
} 
thinking about the nature of human rights'. ${ }^{18}$ 'The meaning of the idea of a human right', he elaborates, 'can be inferred from its role in a discursive practice' ${ }^{19}$

It is important to stress that the inferential authority of practices is, on this understanding, necessarily normative as much as conceptual; indeed, it is normative because it is conceptual. The boundaries for normative theorizing are inevitably fixed by the definitional terms of the concept being discussed - the terms of the conceptual definition frames and limits the normative possibilities available. The implication is that any normative account of a concept that strays beyond practice is, as a matter of verifiable fact, no longer addressing that concept. When engaging in normative theorization, we must, according to Beitz, attend to the 'doctrine and practice of human rights as we find them in international political life as the source materials for constructing a conception of human rights' ${ }^{20}$ He thus defines the idea of human rights in terms of what he regards as its essential, practical function in international relations. ${ }^{21}$ This function is, he claims, to provide an evaluative behavioural standard that states must meet in terms of their domestic conduct. Within the international order, human rights provide reasons for action to states as responsive agents. The practical role of human rights is - upon their violation - to motivate and justify international intervention. ${ }^{22}$ So, when a state fails to protect the human rights of its people, it can expect some justified 'remedial or preventive action by the world community or those acting as its agents' in response. $^{23}$

Along very similar lines, Andrea Sangiovanni maintains - or at least did so when he first wrote on this subject - that any determination of the specific content of human rights

\footnotetext{
${ }^{18}$ Ibid, p. 10, emphasis added.

${ }^{19}$ Ibid.

${ }^{20}$ Ibid, p. 102.

${ }^{21}$ Ibid, p. 8.

22 'Human rights are standards for domestic institutions whose satisfaction is a matter of international concern' (Ibid. p. 128). See also pp. 7-12 and pp. 126-41.

${ }^{23}$ Ibid, p. 13.
} 
must attend to their formal functions within established institutions. ${ }^{24}$ For him, this means that 'rather than aim for a conception of [normative] right in general', it is instead necessary for theorists to begin 'from social and political institutions as they are here and now' ${ }^{25}$ The practical role of a particular right is here again taken to have authority in determining its conceptual and normative meaning. For Sangiovanni, any assessment of the normative and conceptual possibility of a human right requires the eschewal of reference to abstract moral values, such as Griffin's idea of personhood. Such an assessment should rather be concerned to ask, 'what role is this right meant to play in actual political conflicts?' before the possibility of such a right can be countenanced. ${ }^{26}$ This test of functionality is likewise crucial for Joseph Raz's political account of human rights. For Raz, the relevant measure is the 'enforceability' of a human right: his claim is that 'where there is no possibility of fair and reliable enforcement, there is no human right'. ${ }^{27}$ This argument trades on the core assumption that rights are, by definition, enforceable claims, and that in the universalistic terms of human rights, this implies the existence of international legal norms, rules, and institutions.

For Beitz, Sangiovanni, and Raz, normative analysis depends on a conceptual understanding that must defer to real-world practice. Their shared view is that the conceptual and normative meaning of human rights must be determined through reference to political realities: we understand the nature of this concept - and draw normative conclusions about it - through attention to its function in the international order, rather than via abstract philosophical analysis of distinct moral values. If theorists wish to consider whether there

\footnotetext{
${ }^{24}$ Andrea Sangiovanni, 'Justice and the Priority of Politics to Morality', The Journal of Political Philosophy 16:2 (2008), pp. 137-64. Sangiovanni has subsequently tempered his affiliation to the 'practice-based' approach (Sangiovanni, 'How Practices Matter', The Journal of Political Philosophy 24: 1 (2016), pp. 3-23, at p. 15, n. 32; see also, Sangiovanni, 'Beyond the Political-Orthodox Divide'). For critical discussions of Sangiovanni's original account, see Eva Erman and Niklas Möller, 'What distinguishes the practice-dependent approach to justice?', Philosophy and Social Criticism 42: 1 (2016), pp. 3-23; Erman and Möller, 'How practices do not matter', Critical Review of International, Social, and Political Philosophy 22: 1 (2019), pp. 103-118.

${ }^{25}$ Sangiovanni, 'Justice and the Priority of Politics', p. 156.

${ }^{26}$ Ibid, p. 159.

${ }^{27}$ Joseph Raz, 'Human Rights in the Emerging World Order', Transnational Legal Theory 1 (2010a), pp. 31-47, at p. 44. See also Raz, 'Human Rights without Foundations' in J. Tasioulas and S. Besson (eds.), The Philosophy of International Law (Oxford: Oxford University Press, 2010b), pp. 321-39.
} 
should be, for example, a human right to democratic participation or freedom of speech, we must establish first whether such a right would correspond to the function that human rights serve in the international community.

I wish now to suggest that there are fundamental and insurmountable problems with the practice-based approach to human rights that stem ultimately from the indefensible ontological commitment at its heart. We can uncover this ontological commitment by focusing on what Beitz regards as the statist character of the practice of human rights. According to his view,

'...a practice of human rights...might be described as "statist" in at least two senses: its standards apply in the first instance to states, and they rely on states, individually and in collaboration, as their principal guarantors.... [T] he centrality of states to the practice of human rights cannot be denied....The basic facts are clear. The political structure of the world consists of a system of territorially defined political units, each claiming to exercise legitimate political authority within its borders'. ${ }^{28}$

Beitz is here explicit that deference to the authority of practices involves a recognition that, in the world in which we inhabit, states are the politically significant unit, and that human rights must be understood in such terms. The relevant 'facts' of the matter are, for him, that states exist in the world, maintain international society, and are the agents tasked with protecting the human rights of their citizens.

At an empirical level, Beitz's observations about the role of states in the international system seem accurate. States are the unitary agents capable of establishing binding agreements and they are the (customarily relevant) subjects of international law. It is also the case that states are the entities responsible for the protection of human rights, in political as well as legal discourse. Article 13 of the Universal Declaration of Human Rights (UDHR) declares, for instance, that 'everyone has the right to freedom of movement and residence within the borders of each state'. This statement evidently only makes sense in a world of

\footnotetext{
${ }^{28}$ Beitz, The Idea of Human Rights, pp. 128-129.
} 
bordered sovereign states. In addition to the plausibility of Beitz's empirical claims, there are also numerous arguments for the normative significance of states, with increasingly sophisticated explanations as to why established territorial borders might be of moral importance in ways unacknowledged by advocates of cosmopolitan liberalism. ${ }^{29}$ Beitz's reasoning - his argument from the factual existence of states - is nevertheless problematic insofar as it acts to reify and naturalise existing political arrangements and institutions that are entirely contingent, malleable, and dependent on ideational commitments. The ascription of political authority to already existing institutions misunderstands how practices relate to ideas.

We can appreciate this misunderstanding by turning to the influential account of social ontology put forward by John Searle, which is invoked authoritatively by Beitz. In his reference to Searle, Beitz mentions his 'account of the progression from "social fact" to "institutional fact", which, it is claimed, can explain the interpretive primacy ascribed to the functional role of human rights within the practice-based approach. ${ }^{30}$ According to Searle, the key characteristic of social facts - in contrast to 'brute facts' - is that their existence is wholly dependent on human agreement and collective intentionality. His favoured example is money, which can exist as a brute fact in its physical form (as dollar bills and such) regardless of any intentionality, while its status as a social fact (as medium of exchange within an economy) requires a set of specific human beliefs about its agreed function. ${ }^{31}$ Such social facts then become institutional facts when their recognition is codified through the formal identification of relevant rules and the assignation of required rights and duties. ${ }^{32}$

\footnotetext{
${ }^{29}$ Mathias Risse, On Global Justice (Princeton: Princeton University Press, 2012); Lea Ypi, Global Justice and Avant-Garde Political Agency (Oxford: Oxford University Press, 2012).

${ }^{30}$ Beitz, The Idea of Human Rights, p. 9, n. 13; John Searle, The Construction of Social Reality (New York: The Free Press, 1995), pp. 79-112.

${ }^{31}$ Searle, The Construction of Social Reality, pp. 37-43.

${ }^{32}$ In his discussion of institutional facts, Searle mentions the existence of human rights, which he regards as an 'amazing' example of the phenomenon, because the relevant 'status-function' is the sole criterion of being
} 
Searle's understanding of the 'logical structure of institutional reality' is, however, very different from that suggested by Beitz and serves to undermine, rather than underpin, the practice-based thesis. ${ }^{33}$ For Searle, it is the ideas - the collective intentionality (beliefs and desires) - of the actors involved that both creates and maintains institutional facts. Once an institutional fact has been established, and the relevant rules, rights, and duties codified, this does, in his view, create a new sub-class of social reality: when money becomes institutionalised as a medium of exchange rather than merely socially accepted as such, this represents an important shift in the lived reality of a society, one that is bound to influence the attitudes and actions of the individuals therein. This shift to institutional facts nevertheless does not have the implications that Beitz seems to think it has. Indeed, as Searle's analysis implies, and as he explicitly insists, the continued existence of institutional reality is dependent entirely on the continued existence of relevant ideational commitments rather than on any new or separate institutional authority. ${ }^{34}$ It is the beliefs and desires of individuals that remain authoritatively relevant to accounts of human behaviour within the framework of institutional rules and not the institutional rules themselves.

Social practices/institutions and their associated rules cannot be ascribed any such explanatory authority (or ontological primacy) because their very existence is explained by the existence of ideational commitments. Even though Searle is interested in what he calls the 'structure' of institutions, this term does not imply any fixity or determinacy for any account of human action. It may be the case that individuals act in accordance with institutional rules because they are motivated to do so by the existence of such rules. We know, however, that we cannot reduce that intentional motivation to the force of the rules themselves. We know this because our experience of the world shows us that individuals ignore such rules on

human (Ibid, p. 93). See also Searle, Making the Social World: The Structure of Human Civilization (Oxford: Oxford University Press, 2010), pp. 174-198.

${ }^{33}$ Searle, The Construction of Social Reality, p. 94.

${ }^{34}$ Ibid, p. 117. 
various occasions, even when the consequences and risks of doing so are significant. Searle instances the 1992 Los Angeles riots and subsequent looting, and the suddenness of the fall of the Soviet Union, as obvious examples of large-scale rejections of the claimed authority of institutional facts. Such phenomena are attributable to nothing more than shifts in intentionality. ${ }^{35}$

An important element of Searle's theory is the rejection of any 'sharp dividing line' between social facts and institutional facts. ${ }^{36} \mathrm{He}$ uses the example of war to show the slipperiness of the distinction between the two. While we may have an established social understanding of what constitutes a war, this may be quite different from the codified, legal definition of war, which, in turn, is open to significant negotiations and alterations. ${ }^{37}$ The status of human rights would seem to be exactly akin to war in this respect. Although it is true that human rights have a specific legal meaning in international law and so exist as an institutional fact, it is also the case that they exist as a broader social fact recognised across various intellectual and cultural traditions. The iconic status of the UDHR - a document that has no formal status in international law - is striking evidence of this social fact. It came into being as an expression of supra-legal universalistic principles and continues to be invoked as a morally authoritative statement of values in global political contexts. Furthermore, there is no reason why the rights enumerated in this document could not become part of the institutional reality of human rights, since that too is open to a political rethinking at any moment. It could, of course, be the case that recognition of the existence of human rights as a social fact does not always result in their successful protection. This is unsurprising, however, since the protection of human rights - or any rights, for that matter - is never absolutely assured in practice, even when institutionalised.

\footnotetext{
${ }^{35}$ Ibid, pp. 90-94.

${ }^{36}$ Ibid, pp. 88-89.

${ }^{37}$ As Searle points out, the US government was anxious to cast the Korean War as the 'Korean conflict' because it did not satisfy the legal definition of war (Ibid, p. 89).
} 
It is not necessary to embrace the entirety of Searle's account of social ontology to appreciate how it fatally undermines the practice-based approach. ${ }^{38}$ As shown, the practicebased approach asserts that the normative meaning of human rights depends upon its conceptual meaning, which is, in turn, comprehensible only through deference to institutional reality. Normative theorizing is thus inextricably tied to a conceptual definition that is manifested in practice. The relevant and insurmountable challenge that Searle's theory issues to that approach is to explain how and why practices could ever have interpretive authority in determining the meaning of concepts that then frame and limit normative enquiry, when it is practices that are parasitic on concepts and not vice versa. It shows that institutional reality is ultimately ideational in nature, and is maintained by individual intentionality, such that practices do not have the independent authority that they would need to have to fix the meaning of concepts in the manner suggested by Beitz et al.

Searle's account of social ontology shows us where the reasoning behind the practicebased thesis goes awry. In its suggestion that we can only understand concepts through deference to practices, it effectively ascribes practices a kind of ontological authority and priority over the ideas that generate them. In doing so, it insists that institutional reality is a fixed entity in the world, rather than an object of ideational creation and contestation. Beitz suggests that we can only understand the idea of human rights by looking at its institutional manifestation, whereas that very manifestation has a nature and a plasticity that derives from an ideational content that must have interpretive primacy. Acknowledgement of this ideational primacy then implies that human rights is, for the political theorist, first and foremost, just that: an idea, comprised of a set of conceptual and normative beliefs. These beliefs include, for example, that individuals have some rights solely by virtue of their

\footnotetext{
${ }^{38}$ It seems possible, for example, to endorse the central thesis that the creation, maintenance, and reform of social and institutional reality depends on human intentionality, while nevertheless rejecting some of the apparently quasi-naturalistic tendencies of his theory (e.g. Ibid, pp. 86-87) and resisting or rethinking his sanguinity about the role of power in social and political relations (Ibid, p. 94).
} 
membership of a community of humans, that those rights are inviolable, inalienable, and so on. One may, of course, find this idea unconvincing or fanciful, and there could be various and divergent accounts of its justification, but this does not threaten its status as an idea.

The upshot of the interpretive primacy of ideas is that the core thesis of the practicebased approach falls away. Discursive practices and established institutions cannot be taken as conceptually authoritative because such practices and institutions are themselves ultimately ideational in their nature, and their existence depends on the intentionality of the actors involved. The deference to political reality required by the practice-based account ultimately reifies and naturalises the network of agreements that is radically contingent: it ascribes a concrete existence that it does not possess, which, in turn, implies its fixity in the political landscape. Deference to practical reality seems especially inappropriate - and its reification particularly dangerous - in the case of human rights, given that the historical emergence of the relevant institutions and discourses (such as the UN and UDHR) has been relatively recent and has often taken a form that reveals a very specific (and contestable) interpretation of the core ideas they are supposed to express and protect. Such deference puts artificial limits on the imagination of political philosophy.

We can illustrate this concern through focusing on the concept of states that Beitz thinks is necessarily central to the concept of human rights. Beitz worries that we cannot make sense of human rights as the pre-institutional natural rights articulated in early-modern and modern political thought. Unlike natural rights, human rights - such as political asylum depend on the fact of a statist global framework and corresponding institutions rather than a state of nature. For Beitz, 'the essence of such rights is to describe features of an acceptable institutional environment'. ${ }^{39}$ This view instructively encapsulates the misunderstanding of the relationship between ideas and institutions that defines the practice-based approach. Although

${ }^{39}$ Beitz, The Idea of Human Rights, p. 55, emphasis added. 
abstract moral concepts can obviously imply institutional commitments, the precise nature of these commitments is almost always - and certainly in the case of human rights - openended. We know that ideas like dignity and equality are normative values capable of simultaneously commanding widespread support while nevertheless also housing deep disagreement over their practical entailments. Such ideas have no straightforward, uncontroversial, essential institutional implications. Even when institutions are established in the name of such abstract normative values, their natures and practices are always subject to subsequent revision, because their interpretation and ideational contestation is continuous.

The concept of human rights is such an abstract idea and is open to various institutional interpretations. As suggested, a very basic definition of human rights is that individuals have a set of universal entitlements that they possess merely in consequence of their humanity. This idea clearly permits different interpretations and one might conceivably argue that the dominant statist version is an inadequate one, because it solidifies political borders that are (in principle) historically contingent and (in fact) have, until relatively recently, been very different in both their composition and their porousness. It may be the case that the right to asylum in the UDHR assumes the existence of borders and states, but that is no reason for political theorists to do likewise when conceptualising the nature and normative demands of human rights. In a world without states, the right to asylum would certainly need an alternative guarantor, but it could still plausibly be considered a human right, one that some relevant agent is bound to protect. States embody practices and institutions, and practices and institutions reflect and instantiate ideas: the ascription of conceptual (and therefore) normative authority to practices wrongly denies this and reifies one specific, contingent, and arguably impoverished (statist) understanding of the idea of human rights. 
The Searlean account of social ontology reveals the interpretive primacy of ideas over practices in conceptual understanding, but it does not offer any clue as to how we might best theorize about normative values like human rights. So, having indicated the flaws in the practice-based/political approach to human rights, I now turn to explicate an alternative, pragmatist understanding of the concept. As noted in the introduction, pragmatism is an intellectual tradition that has an important methodological association with practices. It may therefore seem intuitive to conflate a pragmatist understanding of human rights with a practice-based approach to political concepts. As I will show, however, the two share nothing substantive in common, because a plausible pragmatist understanding can make sense of the ideational construal of human rights that the practice-based approach denies as a matter of principle. I will further argue that a pragmatist account of human rights - exemplified by a seemingly unorthodox, but nevertheless accurate and faithful interpretation of Rawls' international theory - can overcome the deficiencies of both the practice-based understanding and the moralistic alternative. First, some terminological disclaimers: in ascribing to Rawls a pragmatist account of human rights, I do not wish to suggest that he would necessarily have endorsed this label, nor that it is necessarily an appropriate description of the philosophical identity of his whole body of work, and nor finally that his theory in any way defines or exhausts the contribution that this tradition of thought can make to understanding the concept in question. ${ }^{40}$ I am rather using pragmatist as the best available descriptor for what I argue is Rawls' distinctive philosophical approach to the analysis and justification of human rights.

\footnotetext{
${ }^{40}$ For a comprehensive analysis of the varied contributions of pragmatism to themes in contemporary political philosophy, see Matthew Festenstein, Pragmatism and Political Theory (Cambridge: Polity Press, 1997), and particularly pp. 2-11 for discussion of the difficulties of constructing a singularly labelled intellectual tradition from its diverse affiliates. Rawls' relationship to pragmatism remains underdeveloped in scholarly work, presumably because of the still influential reading of him as an orthodox Kantian, though the recent work of Daniele Botti is addressing this lacuna. See Botti, 'John Rawls, Peirce's Notion of Truth, and White's Holistic Pragmatism', History of Political Thought 35: 2 (2014), pp. 345-77; Botti, 'Rawls on Dewey before the Dewey Lectures, Journal of the History of Ideas 78: 2 (2017), pp. 287-98.
} 
Though diverse as an intellectual tradition, the modern incarnation of pragmatism in normative political philosophy is characterised chiefly by a rejection of any concept of transcultural, supra-historical, or final understanding of truth. Normative principles are instead thought to require justificatory underpinnings that are provisional, contestable, and, above all, local. As Festenstein observes, for the pragmatist, 'moral theories are seen as historical products, expressing and embodying the societies that produce and sustain them'. ${ }^{41} \mathrm{~A}$ pragmatist reading of Rawls' international theory, I suggest, accurately captures both the moral and ideational character of his understanding of human rights as well its consciously restricted justificatory scope. We can thus use Rawls to delineate the intellectual distance between pragmatism and practices. The pragmatist account of human rights that emerges from Rawls' theory can, I argue, potentially overcome the impasse between moral and practice-based approaches to human rights: it can simultaneously reject the practice-based understanding and rise to the challenge of scepticism by recasting the moralistic approach as a culturally limited justificatory project, and thus can carve a path that escapes that the pitfalls that advocates of each position face.

We can begin to see the appeal of the pragmatist account of human rights by considering first what might make the turn to practices (and corresponding turn away from abstract moralising) appear attractive. Its exponents regard the practice-based approach as attractive, in part, because of the challenges posed to the moralistic human rights project by several species of scepticism. ${ }^{42}$ There are, as Beitz notes, a "variety of reasons why someone might doubt the meaningfulness of human rights talk or the practical significance or value of international human rights practice' ${ }^{43}$ These reasons include a philosophical scepticism about the ostensibly universalistic pretentions of human rights, prompted by doubts about there

\footnotetext{
${ }^{41}$ Festenstein, 'Pragmatism, Realism, and Moralism', p. 42.

${ }^{42}$ Beitz, The Idea of Human Rights, pp. 3-7.

${ }^{43}$ Ibid, p. 6.
} 
being a plausible foundation for their existence that does not depend on an unbearably controversial metaphysics. ${ }^{44}$ Griffin's account of human rights, for example, is rooted in the thick metaphysical commitment that there is an ahistorical human nature with a corresponding set of universally shared individual interests. ${ }^{45}$ There is also a more pointedly political scepticism about the supposed utility - or even benignity - of human rights, which is encouraged by historical associations of the concept with the imperial ambitions of Western nation-states, as well as lingering suspicions of its ideological uses in support of contemporary military campaigns. ${ }^{46}$ Even if these forms of scepticism do not undermine the moral or intellectual force of human rights in the minds of its advocates, they nevertheless invite some response.

One response to scepticism about human rights is to recommend a complete rejection of the concept. ${ }^{47}$ Another response is, as discussed, the practice-based approach, which attempts to defend the political salience of the concept while stripping it of its moral content, thus avoiding the difficulties confronted by any controversially universalistic and ahistorical presuppositions. A pragmatist normative account can, by contrast, empower those who wish to defend the idea of human rights against such species of scepticism. It provides theoretical resources for those who accept that the concept of human rights must be analysed - first and foremost - as an idea rather than a practice, and who also think it an idea that is worth cherishing. The best-known pragmatist defence of human rights has been advanced by Richard Rorty. ${ }^{48}$ His philosophical articulation of the value of human rights - what he

\footnotetext{
${ }^{44}$ Ibid, pp. 4-5.

${ }^{45}$ Griffin, On Human Rights, pp. 32-39, 116-120.

${ }^{46}$ Beitz, The Idea of Human Rights, p. 6. For analysis of the historical use of the idea of natural/human rights in the justification of colonial expansion, see Anthony Pagden, The Burdens of Empire: 1539 to the Present (Cambridge: Cambridge University Press, 2015). For a critical discussion of the paradoxical role of the concept of human rights as one of 'the normative sources of empire', see Costas Douzinas, Human Rights and Empire: the Political Philosophy of Cosmopolitanism (London: Routledge, 2007).

${ }^{47}$ See, for example, Raymond Geuss and Lawrence Hamilton, 'Human Rights: A Very Bad Idea', Theoria 60:2 (2013), pp. 83-103.

${ }^{48}$ Richard Rorty, 'Human Rights, Rationality, and Sentimentality', in Rorty, Truth and Progress: Philosophical Papers 3 (Cambridge: Cambridge University Press, 1998), pp. 167-185.
} 
describes as the 'morally superior' status of 'human rights culture' - is explicitly antifoundational, insofar as it rejects any attempt to account for it that relies on universalistic notions of rationality, whether they be Platonic or Kantian. He instead makes the case for the idea of human rights on the basis that it is 'ours', which links to his broader conception of philosophy as an exercise in conversation that aims to reconcile a culture to those traditions that are central to its self-understanding and to its ethical and aesthetic flourishing. ${ }^{49}$ One of Rorty's most arresting contentions is that 'the question of whether human beings really have the rights enumerated' in international agreements 'is not worth raising, ${ }^{50}$ This sentiment obviously puts his approach at odds with both the moralistic and practice-based understandings of human rights, as each is centrally concerned - albeit in different ways with the human rights we 'really have': in terms of either gleaning them from some account of our essential humanity, or through deference to established political reality.

To justify human rights to the sceptic, in place of the foundationalist appeal to a universal human nature, Rorty emphasises the importance of a 'sentimental education', acquired through exposure to narratives of sufferance. Such an education enables affective responses, widening the circle of empathy: a commitment to it behoves us to identify ways for more people to 'imagine themselves in the shoes of the despised and oppressed' ${ }^{51}$ One of the consistent concerns in Rorty's writing is a dethronement of the aspirations of philosophy, through his recommendation of its more explicit alignment with literature and a corresponding recoiling from any positivistic aping of the natural sciences. When it comes to discussions of normative issues, his view is that 'novels rather than moral treatises are the most useful vehicles of moral education' ${ }^{52}$ Crucially, however, it does not follow from this assessment of relative usefulness that Rorty thinks novels are the only such vehicles. Indeed,

\footnotetext{
${ }^{49}$ Ibid, p. 170. See also Rorty, Contingency, Irony, and Solidarity (Cambridge: Cambridge University Press, 1989).

${ }^{50}$ Rorty, 'Human Rights', p. 170, emphasis added.

${ }^{51}$ Ibid, pp. 176, 179.

${ }^{52}$ Rorty, 'Introduction', in Rorty, Truth and Progress, p. 12. See also Rorty, Contingency, Irony, and Solidarity.
} 
in addition to his recommended technique of telling the 'sad, sentimental story' to broaden and deepen empathy, Rorty also points towards the form that anti-foundationalist and historicist philosophical discussions of normative issues might take. ${ }^{53}$ He puts forward the following pragmatist conception of the philosopher's role when considering such issues:

'Philosophers like myself....see our task as a matter of making our own culture - the human rights culture - more self-conscious and more powerful, rather than of demonstrating its superiority to other cultures by an appeal to something transcultural. We think that the most philosophy can hope to do is summarize our culturally influenced intuitions about the right thing to do in various situations'. ${ }^{54}$

On this understanding, the philosophical enterprise is a necessarily modest and limited one: the range of its moral enquiry is located within an established culture with its own collection of beliefs and traditions. It is important to emphasise that such beliefs and traditions do not necessarily limit the sorts of questions that philosophers can ask. The concern is not to set boundaries to the philosophical imagination. The historicist limitation here is rather a justificatory in nature, insofar as we should not expect our proposed answers to such questions to have purchase beyond the community within which our normative conversation is intelligible. ${ }^{55}$

Within the context of our discussion, it is even more urgent to stress that the justificatory limitation demanded by Rorty does not imply any commitment to a specific philosophical method. His pragmatism does not have strict methodological implications. Although so much of Rorty's writing diagnoses and advertises the problems with analytic philosophy, the main targets of his critiques are the myopic tendencies of its practitioners and

\footnotetext{
${ }^{53}$ Rorty, 'Human Rights', p. 185. It is important to stress that Rorty rejects any oppositional understanding of rationality and sentimentality, and so does not see philosophical and literary enterprises as straightforwardly involving only one or the other. See Rorty, 'Justice as a Larger Loyalty', in Rorty, Philosophy as Cultural Politics: Philosophical Papers, Volume 4 (Cambridge: Cambridge University Press, 2007), pp. 42-55, especially pp. 51-53.

${ }_{54}$ Rorty, 'Human Rights', p. 171.

${ }^{55}$ For a robust critical assessment of Rorty's approach to normative political philosophy, which offers a usefully precise account of his 'substantive ethnocentrism', see Festenstein, Pragmatism and Political Theory, pp. 109144. For a more sympathetic interpretation of Rorty's pragmatism, see Michael Bacon, 'Rorty and pragmatic social criticism', Philosophy \& Social Criticism 32: 7 (2006), pp. 863-880.
} 
their (often unquestioned) commitment to scientism, rather than their actual mode of argumentation. ${ }^{56}$ It is the naturalistic, universalistic, and scientistic pretensions of the claims offered within strands of analytic philosophy that repel Rorty, rather than the established theoretical tools of the trade - conceptual analysis through appeals to ordinary language and dialectical reasoning - that he himself deploys across so much of his writing. ${ }^{57}$ Evidence for both Rorty's methodological openness and his commitment to normative theorizing can be found in his admiration for the political philosophy of Rawls. Unlike many of Rawls's original followers, Rorty not only endorses the core theses of his later ('political not metaphysical') work, but also thinks it consistent with his broader liberalism. ${ }^{58}$

In The Law of Peoples, one of his final works, Rawls outlines his normative vision of international relations. Herein, Rawls argues that the domestic theory of political liberalism he developed in his earlier writing should not be thought extendable to the global sphere. ${ }^{59}$ Instead of any universalistic version of his theory of 'justice as fairness', Rawls ascribes normative significance to the sovereignty of idealised, bordered communities of 'peoples'. For the purposes of his theory, the legitimacy of such peoples is unthreatened by however 'arbitrary a society's boundaries may appear from a historical point of view' and depends

\footnotetext{
${ }^{56}$ Rorty's seminal critique of analytic philosophy is Philosophy and the Mirror of Nature (Princeton: Princeton University Press, 1979). For some of his most powerful, later statements on the analytic tradition, which express his suspicion towards any strict understanding of philosophical method and his rejection of a scientistic expert culture among professional philosophers, see 'Analytic and Conversational Philosophy' and 'A pragmatist view of contemporary analytic philosophy', in Rorty, Philosophy as Cultural Politics, pp. 120-130, 133-146.

${ }^{57}$ Rorty's tendency to use analytic philosophy to criticise analytic philosophy makes him a slippery writer to deal with, even for those sympathetic to pragmatism. For a powerful critique of his political philosophy, see Robert Talisse, 'A Pragmatist Critique of Rorty's Hopeless Politics', The Southern Journal of Philosophy 39 (2001), pp. 611-26.

${ }^{58}$ Rorty also has no qualms about referring to Rawls' 'pragmatism' (Rorty, Contingency, Irony, and Solidarity, pp. 57-58).

${ }^{59}$ That Rawls reaches this conclusion in this text should not have been a surprise to those familiar with the 'political' re-articulation of his theory from the 1980s onwards. In his 1995 'Reply to Habermas', Rawls writes 'Justice as fairness is substantive in the sense that it springs from and belongs to the tradition of liberal thought and the larger community of political culture of democratic societies. It fails then to be properly formal and truly universal' (Rawls, 'Reply to Habermas', The Journal of Philosophy 92: 3 (1995), pp. 132-180, at p. 179).
} 
instead on their moral conduct. ${ }^{60}$ Within the global 'realistic utopia' that Rawls sketches, the various discrete peoples that occupy the world are assumed to be characteristically different, in terms of their forms of government, religious affiliations, and levels of internal pluralism. The view he defends in The Law of Peoples is that there is no normative requirement for such societies to be liberal. The political legitimacy of peoples thus depends neither on there being a constitution that is neutral between competing conceptions of the good, nor on the protection of a set of equally distributed liberal rights.

Rawls' restriction of his theory of justice to societies with established liberal and democratic constitutional traditions has outraged cosmopolitan critics, who regard his position as inconsistent with the moral commitments that undergird his domestic theory. ${ }^{61}$ His normative theory of global politics is, however, endorsed by Rorty. When discussing Rawls' theory, one of the things Rorty is keen to make sense of is a political philosophy that is universalistic in its 'reach', but particularistic in its 'validity' ${ }^{62}$ Rorty's account of Rawls' theory is somewhat underdeveloped, but the ostensibly paradoxical thought he offers is that it represents a culturally particularistic defence of universalistic normative values. But what element of Rawls' international theory emerges as universalistic, if he is content to grant the legitimacy of peoples to pursue political arrangements that depart from liberal democratic norms? The answer - the key universalistic concept in his law of peoples - is human rights. The idea of human rights is pivotal in Rawls' international theory: unlike those rights one

\footnotetext{
${ }^{60}$ Rawls, The Law of Peoples (Cambridge MA: Harvard University Press, 1999), p. 38. As well as defending the normative significance of bordered peoples, Rawls invokes the Kantian rejection of the practical possibility of world government to reject full political cosmopolitanism (The Law of Peoples, p. 36).

${ }^{61}$ See, for example, Simon Caney, 'Cosmopolitanism and the Law of Peoples', The Journal of Political Philosophy 10 (2002), pp. 95-123. For a compelling defence of the coherence and consistency of Rawls' position, see Saladin Meckled-Garcia, 'On the Very Idea of Cosmopolitan Justice: Constructivism and International Agency', The Journal of Political Philosophy 16 (2008), pp. 245-71.

${ }^{62}$ Rorty, 'Justice as a Larger Loyalty', pp. 50-51.
} 
might expect to find in a 'reasonable constitutional democratic regime', they are 'a special class of urgent rights' that span otherwise legitimate borders. ${ }^{63}$

In terms of the theoretical debate outlined earlier, Rawls' understanding of human rights is regarded - with curious persistence - as an exemplification of the practicebased/political approach, which Beitz suggests is 'implicit' in The Law of Peoples. ${ }^{64}$ Upon inspection, however, this is a misleading interpretation that should be corrected, both for the sake of interpretive accuracy, and because doing so shows how we can productively appreciate Rawls's theory of human rights along pragmatist lines. The practicebased/political interpretation stems from Rawls' account of the particular 'role' that human rights have within his theory, as well as the absence of any naturalistic grounding for such rights therein. This role of human rights is, for Rawls, formally equivalent to that claimed by Beitz in his reality-based theorization of the international order. In addition to being 'necessary conditions of any system of social co-operation', for Rawls, human rights act to 'restrict the justifying reasons for war and its conduct, and...specify limits to a regime's internal autonomy' ${ }^{65}$ The idea of human rights is also integral to Rawls' typology of peoples, where it serves as a benchmark for their legitimacy. Within the international society that Rawls imagines, liberal peoples must extend toleration - understood as a politically demanding obligation of egalitarian recognition and civility ${ }^{66}$ - to legitimate ('decent') nonliberal peoples, but not to what he calls 'outlaw states'. One of the definitive features of

\footnotetext{
${ }^{63}$ Rawls, The Law of Peoples, pp. 78-79.

${ }^{64}$ Beitz, The Idea of Human Rights, p. 96. Etinson describes Rawls as 'the original proponent of this view' that 'human rights practice ought to be evaluated under the light of a faithful understanding of what it is that the practice aims to do' rather than on moral terms ('Introduction' in Etinson, Human Rights, p. 4), though he provides no textual evidence for this claim. Such interpretations are commonplace: a far from exhaustive list includes, Beitz, The Idea of Human Rights; John Tasioulas, 'Are Human Rights Essentially Triggers for Intervention?', Philosophy Compass 4/6 (2009), pp. 938-50; Gilabert, 'Humanist and Political Perspectives'; Valentini, 'In What Sense are Human Rights Political? A Preliminary Exploration', Political Studies 60: 1 (2012), pp. 180-194; Waldron, 'Human Rights'. Meckled-Garcia is one of few scholars who also rejects the practice-based/political interpretation of Rawls as a misunderstanding of his theory (Meckled-Garcia, 'The Practice-Dependence Red Herring and Better Reasons for Restricting the Scope of Justice', Raisons Politiques 3 (2013), pp. 97-120).

${ }_{65}^{65}$ Rawls, The Law of Peoples, pp. 68, 79.

${ }^{66}$ Ibid, pp. 59-60.
} 
outlaw states is their flagrant rejection of the law of peoples through the violation of human rights, which can then generate the legitimate expectation of 'forceful sanctions' and even ‘intervention’ from other peoples. ${ }^{67}$

As shown, the practice-based approach to human rights is fundamentally flawed because it ascribes interpretive authority for the understanding of political concepts to institutional manifestations of those concepts that are contingent and contestable. The first step towards uncovering the moral (rather than narrowly political) character of Rawls' account of human rights involves understanding that, for him, the conceptual and normative meaning of this concept does not derive from - nor defer to - its practical role or institutional function in international society. For Rawls to hold a practice-based/political theory of human rights, he must think that its conceptual meaning is derived from its institutional nature or role. He does not. This interpretation may be widely accepted, but it is mistaken insofar as it essentially treats Rawls's conclusion as though it were a premise. Unlike Beitz, Rawls does not approach his international normative theory with the concept of human rights already established or defined. The role of human rights in the world is not given or presupposed and Rawls does not use an assumed institutional existence as a starting point for theorizing international politics. He instead derives his conclusion about the role of human rights in international relations from a broader set of moral commitments. Rawls' account of human rights cannot be separated from his whole normative international theory without misunderstanding its logic. His specific conclusion about the role of human rights in that theory thus provides no methodological blueprint for a practice-based analysis of that concept. ${ }^{68} \mathrm{He}$ instead regards human rights as an idea that instantiates and expresses distinct normative values, which are then manifested in an international role.

\footnotetext{
${ }^{67}$ Ibid, p. 81.

${ }^{68}$ Meckled-Garcia makes the related observation that 'the idea of interpreting a practice by attributing a function to it does not feature in Rawls' method at all. He uses the notion of a role for institutions....However, the notion of a role in these cases is that of playing a role within a coherent overall theory of how the elements of a
} 
We can appreciate Rawls' construal of human rights as a moral - rather than purely political - concept through a focus on two other central normative commitments that connect to it within his international theory: the ideas of decency and peoples. The role of decency in his theory is to provide an evaluative normative standard for the boundaries of toleration in and a prerequisite for membership of - the society of peoples. For Rawls, the right to toleration that non-liberal societies are owed by their liberal counterparts is conditional on the satisfaction of this standard of decency with regards to both their internal and external conduct. ${ }^{69}$ In terms of their external relations, decent conduct means that such societies must be non-aggressive, peaceful, and committed to diplomacy and trade. ${ }^{70}$ In their internal organisation, peoples are defined as decent through their observance and protection of human rights, their established and publicly recognised system of moral obligations, and their adherence to a properly administered rule of law. ${ }^{71}$ Decency is evidently a thoroughly moral idea for Rawls - at no point does he make any reference to it as having a practical or institutional instantiation, and it is not clear how it could have - and his view is that the securement of its status depends on the protection of human rights. For him, human rights provide a 'necessary, though not sufficient, standard for the decency of domestic political and social institutions, ${ }^{72}$

So, for Rawls, the idea of decency is supposed to capture a universal moral standard that liberal peoples can reasonably accept and expect from their non-liberal fellows, to secure their equal standing in global society. The second significant moral concept within Rawls' international theory is the idea of peoples. It is an idiosyncratic notion within theories of international politics, which departs from Kant's focus on nations, and the realist (Hobbesian)

political order should fit together. It is a normative notion of role, not a descriptive interpretive one' (MeckledGarcia, 'The Practice-Dependence Red Herring', p. 115, emphasis suppressed).

${ }^{69}$ Rawls, The Law of Peoples, pp. 59-60.

${ }^{70}$ Ibid, p. 64.

${ }^{71}$ Ibid, pp. 65-66.

${ }^{72}$ Ibid, p. 80. 
focus on states. Rawls explicitly casts peoples as moral entities within his idealised schema. Peoples, unlike states, are not merely rational (in terms of seeking to satisfy their own interests) but also reasonable in a moral sense and therefore willing to agree and honour 'fair terms of cooperation'. ${ }^{73}$ Whereas states are customarily ascribed 'the traditional rights to war and to unrestricted internal autonomy', peoples have a 'moral character' whose sovereignty is only 'derived from the Law of Peoples itself' rather than through independent claim or alternative external recognition. ${ }^{74}$ For Rawls, there is an inextricable relationship between the ascription of decency and the existence of peoples. Each of these is, in turn, bound up with his account of the moral sanctity of human rights. The recognition of human rights is a 'necessary' condition for both the ascription of decency and the securement of a peoples' status as such. ${ }^{75}$ Rawls' claim is that the government of any bordered political territory that violates human rights effectively surrenders its status as part of the society of peoples through an assertion of the traditional autonomy associated with states. ${ }^{76}$ Unlike Beitz, who regards the presence of sovereign states as one of the 'basic facts' of the international order, for Rawls they are something of a moral aberration, indicative of a departure from an idealised normative standard and the eclipse of reasonableness by naked rationality.

In The Law of Peoples, Rawls says very little about established practices and institutions in the international order. At no point does he appeal to them to generate authoritative accounts of conceptual or normative meaning. As far as the explicitly moral categories I have just outlined are concerned, he is explicit that 'the Law of Peoples does not presuppose the existence of actual decent hierarchical peoples' and that his account is

\footnotetext{
${ }^{73}$ Rawls, The Law of Peoples, p. 25. Rawls is explicit that the content of the idea of reasonableness he invokes is not a deduction from a Kantian account of practical reason (The Law of Peoples, pp. 86-87). For his distinction between the moral idea of reasonable conduct and the non-moral idea of rational conduct, see Rawls, Justice as Fairness: A Restatement (Cambridge, MA: Belknap Press, 2001), pp. 6-7.

${ }_{75}^{74}$ Rawls, The Law of Peoples, p. 27.

${ }^{75}$ Ibid, p. 80.

${ }^{76}$ Ibid, pp. 25-26. It is thus no accident that Rawls labels such societies outlaw states.
} 
'hypothetical' and 'idealised' ${ }^{77}$ It should now be quite clear why it is a misreading of Rawls' international theory to then ascribe him a practice-based/political understanding of human rights. When it comes to human rights, Rawls again does not derive the meaning of the concept from any pre-moral, or pre-ideational, political understanding. Although he does express a view about the function or role that human rights have in international society - one that notably departs in clear ways from both standard philosophical conceptions and from real-world legal practice - it is evidently a conclusion embedded in a normative theory rather than a premise that provides any kind of methodological blueprint for conceptual and normative analysis. Beitz is therefore mistaken to say that human rights are, for Rawls, 'constructed for certain political purposes' if this is to be taken as contrasting with moral purposes and, in any case, it is their conceptual and normative nature that defines their political purpose rather than vice versa. ${ }^{78}$ Human rights, for Rawls, have the function that they do for moral reasons: they are an integral part of his normative framework, as an implication of the idea of decency and of his account of what makes a distinct society a recognisable moral agent in the world. The idea of human rights is a prominent ingredient in a comprehensive moral scheme, one that is unrelated to the established practices of the realworld international order. Since human rights is a moral concept for Rawls, defined in ideational terms, his evidently cannot be a practice-based theory.

Though it is demonstrably not practice-based, Rawls' understanding of human rights also departs from the orthodox moral approach exemplified by Griffin. As discussed, Griffin attempts a philosophical articulation of human rights that is universalistic. It might be thought that Rawls does likewise with the abstract idea of decency, which is, after all, supposed to

\footnotetext{
${ }^{77}$ Ibid, p. 75, emphasis added.

${ }^{78}$ Beitz, The Idea of Huma Rights, p. 99. As Rawls himself puts it, 'human rights honored by both liberal and decent hierarchical regimes should be understood as universal rights in the following sense: they are intrinsic to the Law of Peoples and have a political (moral) effect whether they are supported locally. That is, their political (moral) force extends to all societies, and they are binding on all peoples and societies, including outlaw states' (Rawls, The Law of Peoples, pp. 80-81).
} 
have a universal form. As intimated, however, the main difference between Rawls and Griffin lies in the scope of justification for their theories. In The Law of Peoples, Rawls does not appeal to any standard of universal justification when offering his international normative theory. He offers a theory that is universalistic in some of its conceptual content - including through the idea of human rights as a global normative standard - but is nevertheless particularistic in terms of its scope. It is, in other words, directed towards members of communities with liberal and democratic traditions, and does not claim authority beyond that realm of justification. ${ }^{79}$ Griffin thus complains that The Law of Peoples 'works outward' from the perspective of a politically liberal society, whereas he is instead comfortable with a more substantive universalism, and is able even to entertain the possibility of 'an objective justification of human rights authoritative for all rational beings' that the pragmatist could not countenance. $^{80}$

Rawls' ambition is not to provide a normative international theory with universal appeal or validity, but rather the far more modest goal of the elaboration of 'the foreign policy of a reasonably just liberal people'. ${ }^{81}$ And, crucially, it is only to such a liberal audience that his theory could be justified. ${ }^{82} \mathrm{He}$ is clear from the outset that 'the Law of Peoples is developed within political liberalism' and that 'the reason we go on to consider the point of view of decent [non-liberal] peoples is not to prescribe principles of justice for them ${ }^{83}$ His theory does not attempt to justify a universalistic vision of political morality but rather offers a realistically utopian normative account of international society for liberal communities. It works outward from its own standpoint in perspectival terms, but ultimately looks inward in terms of the philosophical conversation of which it is part. In his

\footnotetext{
${ }^{79}$ This fits with how the later Rawls regards the boundaries of normative theorizing, where 'we try to work up, from the fundamental ideas implicit in the political culture, a public basis of justification' for our arguments (Justice as Fairness, p. 29, emphasis added).

${ }^{80}$ Griffin, On Human Rights, pp. 23, 137. See also, pp. 48-51.

${ }^{81}$ Rawls, The Law of Peoples, p. 82.

${ }^{82}$ Ibid, pp. 82-83.

${ }^{83}$ Ibid, pp. 9-10 (emphasis added), 58.
} 
interpretation of Rawls, Beitz wrongly infers a practice-based/political reading from the rejection of naturalism in The Law of Peoples. ${ }^{84}$ A pragmatist reading of Rawls' international theory shows that this conclusion does not follow: we can reject the naturalistic grounding for human rights assumed by Griffin while nevertheless conceiving of it as a fundamentally moral idea.

The Law of Peoples exemplifies a pragmatist approach to normative questions at the international level. It is, recalling the language of Rorty, a provisional attempt to philosophically articulate - as compellingly as possible - the best available moral commitments of the culture within which it is located. It is an intervention that seeks to contest the normative meaning of the liberal and cosmopolitan traditions that characterise the political cultures that house and recognise them. This pragmatist understanding of Rawls' overall project also points us towards a productive framework for fruitful - and correspondingly circumscribed - philosophical conversation about the content of the idea of human rights. This may at first seem unlikely. It might be worried that a pragmatist reading of Rawls' international theory merely underscores its supposed conservatism about what human rights there are. Beitz suggests that the list of universal entitlements identified by Rawls falls short of "'human rights proper"' because it does "not include the full complement of the rights found in the international law of human rights'. ${ }^{85}$ Griffin likewise disapproves of Rawls' 'shortened list'. ${ }^{86}$ This view of Rawls as offering a 'minimalist' account of the content of human rights is at once true and misleading. It is certainly the case that the list he provides is a significantly truncated one, designed to capture the moral commitments that decent peoples could - in the liberal imagination - unite behind. ${ }^{87}$ Among the few 'urgent' rights Rawls identifies as human rights are 'the right to life...to liberty... and to formal

\footnotetext{
${ }^{84}$ Beitz, The Idea of Human Rights, p. 98.

${ }^{85}$ Ibid, p. 197.

${ }^{86}$ Griffin, On Human Rights, p. 143.

${ }^{87}$ The human rights generated in his localised and idealised theory depend upon universal agreement and 'cannot be rejected as peculiarly liberal or special to the Western tradition' (Rawls, The Law of Peoples, p. 65).
} 
equality as expressed by the rules of natural justice' as well as 'freedom from slavery and serfdom' and 'security of ethnic groups from mass murder and genocide'. ${ }^{88}$ His list is clearly a minimalist one when contrasted with both international law and the UDHR.

Rawls nevertheless seems clear that the specific list of human rights he offers is both provisional and contestable and his overall theory permits alternative, more generous interpretations. We can appreciate the provisional nature of Rawls' substantive conception of human rights through further consideration of his explication of decency as the definitive measure for membership of the society of peoples. For him, a decent but non-liberal society such as his imaginary Kazanistan - is one in which human rights are protected, but where there is a hierarchical, non-democratic form of government, as well as an absence of the full catalogue of rights found in a liberal society. One of Rawls' suggested measures of decency for a hierarchical society is a meaningful commitment to representative processes, such that even where members of specific religious or ethnic groups are prohibited from involvement in decision-making procedures, they are still properly consulted through some means, and their interests regarded always as part of the public good. ${ }^{89}$ At a crucial, though overlooked, point of his discussion, Rawls addresses a particular challenge that such a hierarchical society might face to secure its decency and thus cement its status within the society of peoples. He considers the representation of 'members of a [hierarchical] society, such as women, who may have long been subjected to oppression and abuse, amounting to the violation of their human rights'. ${ }^{90}$ Rawls' view is that one way to respond to this historical legacy of oppression - and ensure the consultation of such a historically marginalised group - would be to insist that there be descriptive representation within the group consultation, such that the

\footnotetext{
${ }^{88}$ Ibid, pp. 79, 65 .

${ }^{89}$ Ibid, pp. 71-72.

${ }^{90}$ Ibid, p. 75.
} 
inclusion of women is guaranteed..$^{91}$ The importance of this descriptive representation would, in this instance, thus trump any value attached to the peoples' established hierarchical structure, which could otherwise have guaranteed the formal exclusion of that marginalised group from political consultation. ${ }^{92}$

We can identify a clear and important tension here between, on the one hand, the protection of the discretionary right of the non-liberal society to organise itself hierarchically and, on the other, the protection of human rights. In a revealing footnote, Rawls raises the possibility that 'full democratic and liberal rights are necessary to prevent violations of human rights' as a solution to this problem. ${ }^{93}$ He then explicitly recognises the potential legitimacy of this solution, acknowledging that such a conclusion - that there is a normative requirement for a human right to some degree of political participation - 'may be true' under such circumstances. ${ }^{94} \mathrm{He}$ describes this as a truth to be determined by 'empirical' evidence rather than 'conceptual' argument. In other words, although he himself is not personally convinced that there necessarily is a human right to democratic participation, his theory is clearly open to the possibility that there may be such a right, depending on the force of the available empirical evidence. This openness to a more capacious understanding of which specific human rights are conceivable obviously helps cast Rawls’ own minimalist conception in a new light and illustrates how the theoretical framework he develops enables fruitful further thinking about the content and implications of that idea. In fact, we can appreciate how his understanding of human rights does not foreclose the sort of normative analysis undertaken by Griffin and others, provided its justificatory claims are appropriately

\footnotetext{
91 'One step to ensure that their claims are appropriately taken into account may be to arrange that a majority of the members of the bodies representing the (previously) oppressed be chosen from among those whose rights have been violated' (Ibid).

${ }_{92}$ Ibid.

${ }^{93}$ Ibid, n. 16.

${ }^{94}$ Ibid.
} 
localised. Rawls' approach invites an open-ended philosophical discussion about the specific content of human rights.

\section{Conclusion}

The aims of this paper have been to articulate a pragmatist framework for theorizing human rights and, in doing so, distinguish it from the recently ascendant practice-based approach with which it might wrongly be conflated. In the first part, I showed that the practice-based approach to human rights is defined by its ascription of conceptual and normative authority to practices and institutions, at the expense of abstract moral ideas. Drawing on Searle's social ontology, I argued that the practice-based approach inevitably naturalises and reifies political institutions that are radically contingent, because it ignores the interpretive primacy that ideas must have for interpreting and contesting those institutions. Theorists of human rights need therefore to work with an ideational rather than practice-based understanding of the concept. In the second part, I outlined and commended an alternative, pragmatist account of human rights, which is ideational and moral rather than practice-based and political. I argued that a pragmatist reading of Rawls' normative international theory is both interpretively accurate (and so undermines the orthodox understanding of it as the original source for the practicebased approach), and also philosophically productive (in that it shows how the account of human rights in The Law of Peoples is an open-ended one capable of stimulating further debate about the normative demands of that idea). Rawls offers an exemplary theoretical articulation of a value that is universalistic in its substantive meaning, but particularistic in terms of the scope of its justification.

It might be worried that Rawls' pragmatism posits a reification of its own, through his commitment to the idea of traditions within which moral justification takes place and the 
peoples/communities with whom it is intended to resonate. ${ }^{95}$ Does Rawls ascribe a concrete existence to entities that are, in fact, contingent, malleable, and porous? There are good reasons to think not. These reasons relate to the nature of traditions themselves and the communities that house them. Whereas practices and institutions can be reified when their ideational roots are forgotten, the fundamentally ideational character of the intellectual tradition that Rawls invokes means that it can only ever be claimed and contested: traditions have no essential characteristics but are rather constructed through theories like Rawls'. The Law of Peoples thus instantiates a contestation of the very liberal tradition that he appeals to. His theory is provisional in its content and is not presented as definitive of his community, not least because he acknowledges that there are 'many liberalisms' ${ }^{96}$ Rawls' account of human rights and the content of the law of peoples can always be disputed through an alternative interpretation of the liberal tradition that it claims. It is also possible for his ideas to have salience and uptake beyond the community that is appealing to - his claim is just that we should not necessarily expect them to. 'Peoples' are therefore best understood as an idealised moral concept that draws on intellectual commitments that should be recognisable to members of a community with a liberal tradition, rather than thought to have any real existence.

Another worry might be that a pragmatist reading of Rawls provides a vision of political impotence, with a particularistic justification threatening the universalism that gives human rights their unique normative force. One of the alleged weaknesses in Rorty's account of human rights is that it effectively disables the concept, because its location in a specific community renders any trans-cultural critique illegitimate. ${ }^{97}$ Rawls himself is clear in his own theory that a commitment to human rights does not entail a politics of communitarian retreat,

\footnotetext{
${ }^{95}$ For discussion of this worry about reification of cultural attitudes towards human rights, see Amartya Sen, 'Human Rights and Asian Values', New Republic 217: 2-3 (1997), pp. 33-40.

${ }^{96}$ Rawls, The Law of Peoples, p. 57. See also p. 10.

${ }^{97}$ Brian Schafer, 'Human Rights: Problems with the Foundationless Approach', Social Theory and Practice 31 : 1 (2005), pp. 27-50.
} 
but rather one of cosmopolitan outreach. For him, violations of human rights would - under the law of peoples - demand international policies such as economic sanctions, and military interventions in situations of moral emergency. Such violations do, of course, presuppose the enshrinement of the law of peoples, which, in turn, depends on there being a global consensus on the moral idea of decency. Since decency is the moral basis for human rights, Rawls thinks that it is not a peculiarly liberal value and therefore believes that such a global consensus is feasible. His belief in such feasibility must nevertheless ultimately be a matter of hope rather than certainty because of the circumscribed justificatory scope of his theory.

As noted, the pragmatist account of human rights is necessarily tentative, provisional, and limited in terms of its normative authority. This means that the accounts of Rorty and Rawls are, by definition, incapable of providing a universalistic justification for the idea of human rights, even though that idea is universalistic in its form. Whether this appears to entail a political paradox will depend on what one thinks the philosophical enterprise can, or should, do. Any worry about the political disablement of human rights must presuppose the possibility of an alternative, universalistic theory that can tell the world exactly what human rights demand. If, however, one agrees with Rorty that the most political philosophy is capable of doing is providing the best possible articulation of normative values within traditions, then the worry about the universality of human rights evaporates. What we are left instead with is the hope that we can convince ourselves, our community, and then maybe others of the attractiveness of those values. When we look to other cultures and criticise them - through whatever means - for violating what we regard as human rights, we are advancing perhaps the most serious charge we have within our moral vocabulary, but it is nevertheless a contingent charge, and whether it implies the legitimacy of international intervention without the kind of global consensus about decency invited by Rawls must remain an open question. 
For Rawls, in our philosophical deliberations, 'we must always start from where we now are' ${ }^{98}$ In his international theory, he thus helps reimagine the nature of political philosophy, as a conversation that begins within shared intellectual traditions, rather than an activity that seeks anything more transcendent. Rawls is clear that The Law of Peoples is not a 'treatise' on international law, but rather his sketch of a realistic utopia within a specific cultural context. ${ }^{99}$ His approach is not relativistic, because it does not chain justificatory authority to existing traditions in such a way as close them off and accept existing beliefs and practices as they are; it rather allows those traditions to be contested through open enquiry in a manner that recognises both their contingency and our situatedness. A pragmatist reading of Rawls ultimately enables an avoidance of both moral and political culs-de-sac within recent philosophical discussions of human rights. It avoids the reification and naturalisation of established political arrangements that is an inevitable feature of the practice-based approach. It avoids what might be regarded as the naïve universalism of the moral approach, which mistakenly regards ethnocentrism as a justificatory problem to be overcome rather than a commitment that must be owned up to. The pragmatist account of human rights - demanded by Rorty and exemplified by Rawls - instead provides a path to follow that enables further normative philosophical conversations about an idea that is still regarded by many to be the crowning achievement of modernity.

\footnotetext{
${ }^{98}$ Rawls, The Law of Peoples, p. 121.

${ }^{99}$ Ibid, p. 5.
} 